\title{
University Talents Training Mode based on Ability
}

\author{
Xiaosheng Lei
}

School of management, Hubei University of Chinese Medicine, Wuhan Hubei, 430060, China

Keywords: Ability; Practice, Colleges and universities, College students, Teaching.

\begin{abstract}
This article selectively analyzes some problems in the teaching process of colleges and universities, exploring the role and significance of strengthening the ability training in the process of college students' learning and putting forward specific patterns and measures for ability-based college students training on aspects of teaching idea transformation, theory with practice, optimization of practice, the expansion of the campus practice teaching infrastructure, the off-campus practice business contact, the transformation of teachers' team etc.
\end{abstract}

\section{Introduction}

In the modern university, high quality technical and skilled talents need to have more ability exercise to have their own unique and creative way of thinking when solving a problem, realizing an effective solution. This practice ability is very important to college students' career development. College graduates need to face the grim employment situation. Therefore, they must develop good learning habit when at school. Colleges and universities should be a place for training students' ability of practice and effectively exercising students' ability of independent thinking during the teaching process. Therefore, as for effective training of high-quality talents, teaching of theory with practice needs to be expanded continuously, enthusiasm of students to participate in practice needs to be continuously improved ${ }^{[1]}$.

\section{Problems in traditional teaching of colleges and universities}

Simplification of teacher's teaching method.

Higher education teaching follows the step by step teaching method. The traditional teachers' means of teaching knowledge is relatively single by just relying on a piece of chalk, while curriculum teaching methods lack of diversification, students' learning interest and enthusiasm insufficient. The update of teaching content of some subjects which have relatively fast development process is insufficient, not able to keep pace with the times. Students are lack of new knowledge as well as necessary innovative thinking to related courses. Therefore, the important role of theory with practice teaching needs to be expanded continuously. Some teachings are lack of innovation consciousness, no more innovation of teaching methods and means in the process of teaching, with teaching content old-fashioned, teaching atmosphere not active, in such an environment students are lack of the necessary innovation spirit and consciousness.

\section{Poor comprehensive ability of students.}

With continuous expansion of colleges and universities in recent more than ten years, higher education has been changed from elite education to mass education. Students are lack of comprehensive ability generally, for example, on the initiative of learning, some students' fear will arise once their learning become more difficult. Once they meet some relatively big difficult problems, they will avoid them and even blame teacher's teaching. However, what higher education needs to follow is the continuity of knowledge points, once a knowledge point is not well grasped, the learning effect of the course will be influenced directly. As for some professional classes with larger difficulties, once the examination result is not satisfactory, students will have negative comments on the teacher. This reflects to some extent the comprehensive learning and practical ability of a few students are relatively low. 


\section{Lack of practice places and opportunities.}

At the stage of education in colleges and universities, most modern majors belong to the type of application. During the process of teaching, there are a lot of practical experiment. However, because the colleges and universities need a lot of money on investment in practice teaching, due to the lack of funds, some schools have certain deficiencies on purchase of experimental equipment, professional experiment teacher training. Besides their contact with the outside world is not very close. All these result in students' relatively less practice time and opportunities. Once the using fault of equipment appears, a lot of maintenance costs would be needed. So some schools leave students limited experiment practice.

\section{The meaning of strengthening ability education as the core of education in colleges and universities}

\section{Optimizing the new concept of talents cultivation.}

Talent cultivation plan is not only just an outline of professional teaching plan, but more a directional file of the modern universities in specific teaching. It has a guiding significance on major development in the future. With the need of continually highlighting the practicality of professional talents of modern colleges and universities, the content of this part needs to be increased in the new talents training plan to realize update and optimization of talents training concept. Only in this way can the practice training needs of the professional talents be better satisfied.

\section{In line with market needs.}

In modern society, the ability and the quality of the industry personnel in all walks of life need to be further enhanced to win the market. Enterprises' competition is ultimately the talents' competition. To have an impregnable position in the incentive market competition, when choosing talents, these enterprises are required to choose those graduates who have practical experience and innovation management ability, able to enter faster into the positions and roles in the actual work and better adapted to the development rhythm of the enterprise.

Inspiring students' enthusiasm to participate in teaching.

Ability training requires students to organize more situational teaching practice. It has broken the traditional cramming teaching mode through the interactive teaching mode. College students have a very strong interest to this kind of interactive teaching, they are eager to participate in this interactive teaching. As a result, the enthusiasm of students of participating in teaching is effectively motivated. At the same time, this using theory to guide practice brings students curiosity. College students have more interest for this kind of unknown problems, therefore, curiosity is also an important factor to stimulate students to participate in the teaching and improve the motivation of learning ${ }^{[3]}$.

\section{Fostering the students' ability to study on their own.}

The cultivation of abilities belongs to one part of quality teaching. Teachers' guiding students to develop a good study habit helps to improve the learning ability of students. For example, the use of a period of time for professional knowledge intensive reading in the morning, using the extracurricular activities to organize professional theory communication, all these leavening influence will be directly affected on students' professional learning ability and make students like the courses learning, actively learn related knowledge and finally form good learning habits to realize the promotion of the self-study ability of the students.

\section{Optimizing the teaching atmosphere.}

Ability training needs a good university study atmosphere. This ability training requires teachers to implement more measures in teaching methods and means(for example: multimedia courseware can foil the teaching atmosphere of ability training; Situational teaching can simulate a situation to practice the attainment and ability of students etc.) to optimize the university teaching atmosphere continuously. So this ability training can optimize the university teaching atmosphere step by step. Only in good university communication atmosphere can students achieve the ascension of attainment and ability. 


\section{Specific measures for construction of ability training of University talents education}

\section{The teaching concept transformation.}

The construction of university students' ability training objectives needs to be started from education concept of colleges and universities to realize cultivation of students' comprehensive ability, to carry out the optimization and supplement of talents cultivation plan targetedly in allusion to the weak link in traditional college talents training mode, namely to implement more systematic, diversified teaching training in the practice link of students' professional knowledge, to improve students' interest in learning theory knowledge and to expand students' application level and ability as well as realize the students' initiative to participate in teaching continuously from the perspective of practice. All these can be realized only by teachers' continuing to expand their teaching ideas and thoughts in the teaching process.

\section{Realizing the curriculum's theory with practice teaching.}

In the process of theoretical teaching, the combination of theory and practice needs to be highlighted. Because college students' social orientation are applied talents in the future, in the process of teaching, the case type teaching way needs to be continuously highlighted, in the process of the interpretation of relevant theoretical knowledge, related practical cases need to be supplemented continuously, in this way, students can be better helped to understand the relevant theoretical knowledge and realize the efficient promotion of their speciality accomplishment. In the meantime, the enthusiasm of students' participating in teaching also needs to be further promoted in the teaching process. That is to say, applying some teaching links with students' participation, for example, task-based teaching approach, dividing students into different study groups and decorating related practice tasks for them to let them do group cooperation, search relevant document literature, do actual operation in simulation laboratory, training base etc. Eventually students will do achievement report, and the teacher have concluding speech, this will further stimulate the initiative of students to participate in teaching. At the same time, expanding the opening experiment. Students have a strong spirit of innovation, technology practice has more exploration directions. Teachers can have targeted research practice exploration on students according to the actual situation of students, this teaching method can realize the promotion of innovative spirit of students to explore the unknown, help them to establish the confidence and motivation of investigative study. In the practice of the social survey course, it can give students the relevant requirements of investigation, provide necessary investigation guidance and tools and then let the students be divided into different groups to operate respectively, this kind of practice which requires students to compile questionnaire, on-the-spot investigation, collect data, analyze and handle data creates an opportunity for students to have independent thinking and mutual collaboration ${ }^{[4]}$.

\section{Opportunities to optimize the practice teaching.}

Practical training inside school is the key link the high quality technology applied talents training in colleges and universities needs to implement, therefore in the process of teaching plan design, it needs to constantly give prominence to the professional settings of the practice teaching in the whole major setup process, as much as possible to increase the relevant campus training time and opportunity. In the conditions allow, to realize opening related training laboratories in the spare time and at the same time further expand the practice teaching content of open mode, continuously cultivate students' ability to solve the problem. Specifically, it first needs to further expand the teaching design of the related experiment courses to have effective training on students ' practical ability. Such teaching content can be more applied to the teaching process to continuously change the teaching concept of "Only focusing on theory teaching, neglecting practice link". Second, the content of practice teaching needs to be further optimized. That is, there are a lot of teaching knowledge points needs to be grasped in the teaching link, the effective preposition of practice teaching content, related practical problems be set before the course, let students think, conduct practice activities with problems, in this way, it can make students grasp the related practice content better. 


\section{Extend the on campus practice teaching infrastructure.}

To practice in the campus is the main form for the practical teaching of applied courses in colleges and universities. It is very important to the cultivation of student's manipulative ability, innovation consciousness. Therefore some constructions of classrooms for professional practice of applied courses need to be increased in the process of construction of school infrastructure. For instance: simulation practice classroom, for example, this kind of training bases can effectively simulate the teaching of management. This kind of training bases can cultivate students' comprehensive professional basis skills through self test of management knowledge and ability, scenario simulation case analysis, group discussion etc. The diversity of teaching aids needs to be highlighted to realize more diverse learning of students when carrying on the practice teaching.

\section{The contact with the off-campus practice training enterprises.}

Realizing college-enterprise cooperation in school running, carrying out the professional talents training in a form of cooperation between colleges and enterprises through cooperation with enterprises can not only let students have a stable job after graduation, at the same time increase the students' internship opportunities in the enterprise. The simulation of various working environments in simulation laboratories, practice training places of the school has some limitations. Only through practice internship in an enterprise can students actually feel the working environment atmosphere of an enterprise and really understand some theoretical knowledge the course teaches, thus their interest of participating in practice during the teaching process. Schools need to establish a long-term relations of cooperation with relevant health care organizations or medicine enterprises through various approaches according to the situation of their own graduates. On the one hand the schools can provide practical talents for these enterprises' need, on the other hand these enterprises can provide school students with the opportunity to practice. Schools send students on a regular basis to the related enterprises for practice, while enterprises can sign a letter of intent for work with the satisfied students.

\section{The transformation development of teacher troop.}

Colleges and universities need to break out the concept of elite education and realize the change from the theoretical type to the "double-certificated teachers" with integration of theory with practice. The concept of the so-called "double-certificated teachers" is to divide teachers' ability of literacy into two levels--theory explanation and practice experience. In higher education, students need to learn not only professional theory knowledge, at the same time also should constantly enrich their practical experiences, in this way they can be more adaptable to the needs of job position in the actual work while their practice ability and experience will continuously be improved. Therefore the key point of the cultivation of double-certificated teachers troop is the practical ability development of the teachers, encouraging the teachers to go deep into the practice in the enterprises by utilization of their spare time, to accumulate relevant work experience and enrich their work experience continuously in the work, and thus they can bring the practice work into the teaching process to explore new teaching cases and subject matters.

\section{Conclusion}

High quality talents' professional technology and skill should be better than those of general professional personnel. This kind of promotion of ability and accomplishment requires to continuously highlight the change of teaching ideas, connection between theory and practice, the optimization of practice opportunity, the expansion of on campus practice teaching infrastructure, the contact with off-campus practice training enterprises, the transformation of teacher troop, thus the ability and accomplishment of college students will be effectively promoted.

\section{References}

[1] Sun Yanping, Lu Yan, Liu Kai Qiang etc. The exploration of colleges and universities' cooperation education mode used by industry-university-research cooperation on innovative 
talents training, 2013 3rd International Conference on Education and Education Management(EEM 2013), 2013,11:184-185.

[2] Zhu Bei, Zhao Ye Jiong, Wang Yan etc. Exploration on innovative talents training mode in local colleges and universities under the perspective of industry-university-research cooperation, 2012 2nd International Conference on Education and Education Management(EEM 2012), 2012, 09:176-177.

[3] Wen Xiaxia, Du Zi Xue etc. New thinking on colleges and universities'vehicle engineering major talents practice training mode, 2011 International Conference on Software Engineering and Multimedia Communication(SEMC), 2011,07:192-193.

[4] Gao Li Hua, Fan Cuicui, Meng Yanze, Yang Jun etc. Conducting creative teaching for real, trying efforts to cultivate creative talents--research on the teaching mode reform of colleges and universities takes the humanistic thought as the concept, 2010 Third International Conference on Education Technology and Training (ETT 2010), 2010, 11:124-125. 